Indonesian Journal of Cardiology

Indonesian J Cardiol 2018:39:174-185

pISSN: 0I 26-3773 / elSSN: 2620-4762

doi: I0.3070I/ijc.v39i4.702

\title{
Performance of Simplified Acute Physiology Score 3 in Predicting Mortality in Intensive Cardiovascular Care Unit
}

\author{
Akhtar Fajar Muzakkir1 2,4, Dafsah Arifa Juzar4,5, Andi Alfian Zainuddin3, \\ Dwi Yuda Herdanto4, Bambang Widyantoro4,5, Dian Zamroni4,5, \\ Siska Suridanda Danny4,5, Isman Firdaus4,5, Daniel PL Tobing4,5, Irmalita4,5
}

I Cardiology and Vascular Medicine Department, Faculty of Medicine, University of Hasanuddin 2PJT RSUP Dr. Wahidin Sudirohusodo, Makassar ${ }^{3}$ Community Medicine Department, Faculty of Medicine, University of Hasanuddin

${ }^{4}$ National Cardiovascular Centre Harapan Kita, Jakarta; ${ }^{5}$ Cardiology and Vascular Medicine Department, Faculty of Medicine, University of Indonesia

\section{Correspondence:}

dr. Akhtar Fajar Muzakkir

Departemen Kardiologi dan

Kedokteran Vaskular, Fakultas Kedokteran Universitas Hasanuddin RSUP Dr. Wahidin Sudirohusodo, Makassar

E-mail: akhtarfajarmuzakkir@ gmail.com

\begin{abstract}
Background: Severity of illness scoring systems has gained increasing popularity in Intensive Care Units (ICUs) since 1980s. Physicians used them for predicting mortality and assessing illness severity in clinical trials. The Simplified Acute Physiology Score 3 (SAPS 3) is the only score that can predict hospital mortality within an hour of admission to ICU. Although this scoring system has been widely used in ICUs, they have not been commonly applied in Intensive Cardiovascular Care Units (ICVCUs) since the population is quite different especially in disease subset. Therefore, the objective of this study was to evaluate the parameters in the SAPS 3 scoring system performance for predicting mortality in ICVCU population.

Methods: This was an observational study with cross-sectional approach using secondary data from RAICOM (Registry of Acute and Intensive Cardiovascular Care on Outcome) taken from September 2013 - September 2014 in the National Cardiovascular Centre Harapan Kita ICVCU, Jakarta, Indonesia. The secondary data were collected, analyzed, and matched with SAPS 3 variables. All missing and invalid data were excluded. All data were processed and the SAPS 3 score was calculated in each patient. Multivariate analysis with logistic regression was conducted to evaluate the significance of the parameters in predicting mortality. Discrimination was assessed by area under the receiver operator characteristic curve (AUC). Calibration was assessed by Hosmer-Lemeshow goodness-of-fit test through calculating the ratio of observed-to-expected numbers of deaths.

Results: A total of 233 patients were included in this study and the observed in-hospital mortality was $16.7 \%(39 / 233)$. The patients enrolled were divided into survivors and nonsurvivors groups. Bivariate analyses of SAPS 3 variables showed intra-hospital location before ICVCU admission, use of vasoactive agents, reasons for ICVCU admission, infection, Glasgow Coma Score (GCS), creatinine level, and platelet count were significantly different between groups $(P<0.05)$. The SAPS 3 score was significantly higher in nonsurvivors than survivors. The AUC ( $95 \%$ confidence intervals [Cls]) for SAPS 3 score was 0.752 (0.669-0.835). The Hosmer-Lemeshow goodness-of-fit test for SAPS 3 demonstrated a Chi-square test score of $1.729, P=0.943$. Multivariate logistic regression was conducted for all variables that were probably correlated to prognosis. Intermediate ward as intra-hospital location before ICVCU admission was independent risk factor for predicting mortality (OR 4.165; 95\% Cl I.462-II.864; $P=0.008$ ), whereas the presence of community-acquired pneumonia (CAP) before ICVCU admission was surprisingly a protective factor towards it (OR $0.224 ; 95 \% \mathrm{Cl} 0.068-0.730 ; P=0.013$ ).

Conclusion: Parameters in the SAPS 3 score system exhibited satisfactory performance in discrimination. In predicting hospital mortality, these parameters also showed good calibration for estimating inhospital mortality. Intermediate ward as intra-hospital location before ICVCU admission appeared to be independently associated with mortality, while CAP comorbid became protective against it. Despite the good result of this study, there are still plenty room of improvement for developing similar score in the future specifically for ICVCU population.
\end{abstract}

(Indonesian J Cardiol. 2018;39:174-185)

Key words : Hosmer_Lemeshow goodness_of_fit Test; Intensive Cardiovascular Care Unit, Independent Risk Factor; Probability of Hospital Mortality; Prognosis; Receiver Operating Characteristic; Simplified Acute Physiology Score 3 


\title{
Performa Simplified Acute Physiology Score 3 sebagai Prediktor Mortalitas pada Unit Rawat Intensif Kardiovaskular
}

\author{
Akhtar Fajar Muzakkir 1,2,4, Dafsah Arifa Juzar4,5, Andi Alfian Zainuddin3, \\ Dwi Yuda Herdanto4, Bambang Widyantoro4,5, Dian Zamroni4,5, \\ Siska Suridanda Danny 4,5, Isman Firdaus4,5, Daniel PL Tobing4,5, Irmalita4,5
}

\begin{abstract}
Abstrak
Latar Belakang: Sistem penilaian berdasarkan derajat keparahan penyakit telah banyak digunakan di Unit rawat intensif/Intensive care unit (ICU) sejak kisaran tahun 1980. Sistem ini digunakan untuk memprediksi mortalitas dan menilai derajat keparahan di uji klinis. Simplified Acute Physiology Score 3 (SAPS3) merupakan satu-satunya skor yang dapat memprediksi mortalitas di rumah sakit dalam jam pertama perawatan di ICU. Walaupun system ini telah banyak di gunakan di ICU, namun belum banyak digunakan di Unit rawat kardiovaskular intensif/ intensive cardiovascular care unit (ICVCU) dikarenakan populasi pasien yang berbeda. Tujuan dari studi ini adalah untuk mengevaluasi parameter skoring SAPS3 dalam memprediksi mortalitas di ICVCU

Metode: Penelitian ini merupakan studi observasional dengan pendekatan cross-sectional menggunakan data dari RAICOM (Registry of acute intensive cardiovascular Care on Outcome) selama september 2013 - September 2014 di ICVCU pusat jantung nasional harapan kita. Data sekunder dikumpulkan, dianalisis dan dicocokkan dengan variabel-variabel SAPS3. Semua missing data di eksklusi dari studi. Skor SAPS3 dihitung untuk tiap pasien. Kami melakukan Analisis multivariat dengan regresi logistik untuk menilai signifikansi dari parameter yang dapat memprediksi mortalitas. Diskriminasi dinilai menggunakan Area under the curve (AUC). Kalibrasi studi dilakukan dengan Tes Hosmer-Lemeshow Goodness-of-fit dengan menghitung rasio dari jumlah kematian yang diprediksi dengan yang dimati

Hasil: Terdapat 233 subyek penelitian yang di inklusi pada studi ini. Jumlah kematian saat perawatan di RS sebesar 16.7\% (39/233). Pasien yang masuk dalam studi dibagi dalam kelompok penyintas dan nonpenyintas. Analisis Bivariat dari SAPS3 menunjukkan variabel-variabel lokasi perawatan sebelum ICVCU, penggunaan agen vasiaktif, alasan perawatan di ICVCU, infeksi, Glasgow coma Score (GCS), kadar kreatinin dan hitung trombosit memiliki perbedaan yang signifikan antar dua kelompok $(\mathrm{P}<0.05)$. Skor SAPS3 secara siginfiikan lebih tinggi pada grup nonpenyintas disbanding grup penyintas. AUC $(95 \% \mathrm{CI})$ untuk skor SAPS3 sebesar 0.752 (0.669-0.835). Tes Hosmer-Lemeshow goodness-of-fit untuk SAPS 3 menunjukkan hasil chi-square sebesar 1.729, $\mathrm{p}=0.943$. Analisis multivariate regresi logistik dilakukan untuk semua variabel yang berhubungan dengan prognosis. Lokasi perawatan di intermediate ward sebelum perawatan ICVCU merupakan faktor resiko independen terhadap prediksi mortalitas (OR 4.165; 95\% CI 1.462-11864, $\mathrm{p}=0.008$ ), ditemukan juga community acquired pneumonia (CAP) sebelum perawatan ICVCU memberikan efek protektif terhadap kematian ( OR 0.224); 95\%CI 0.068-0.730; $\mathrm{p}=0.013$ ).

Kesimpulan: Parameter skoring SAPS3 menunjukkan performa yang memuaskan dalam studi ini. Dalam memprediksi mortalitas di rumah sakit, parameterparameter ini menunjukkan kalibrasi yang baik dalam memprediksi angka kematian selama perawatan di RS.
\end{abstract}

(Indonesian J Cardiol. 2018;39:174-185)

Kata Kunci: Hosmer_Lemeshow goodness_of_fit Test; Intensive Cardiovascular Care Unit, Independent Risk Factor; Probability of Hospital Mortality; Prognosis; Receiver Operating Characteristic; Simplified Acute Physiology Score 3

ICardiology and Vascular Medicine Department, Faculty of Medicine, University of Hasanuddin

2PJT RSUP Dr. Wahidin Sudirohusodo, Makassar

${ }^{3}$ Community Medicine Department, Faculty of Medicine,

University of Hasanuddin

${ }_{5}^{4}$ National Cardiovascular Centre Harapan Kita, Jakarta

${ }^{5}$ Cardiology and Vascular Medicine Department, Faculty of

Medicine, University of Indonesia

Korespondensi:

dr. Akhtar Fajar Muzakkir

Departemen Kardiologi dan Kedokteran Vaskular, Fakultas

Kedokteran Universitas Hasanuddin RSUP Dr. Wahidin

Sudirohusodo, Makassar

E-mail: akhtarfajarmuzakkir@gmail.com

\section{Latar Belakang}

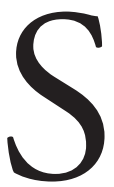

istem skor prediktif yang menilai tingkat keparahan penyakit dapat digunakan untuk memprediksi luaran pasien khususnya mortalitas pada unit perawatan intensif (intensive care unit - ICU) ${ }^{1}$. Acute Physiology and Chronic Health Evaluation Score 2 (APACHE 2) ${ }^{2}$ dan Simplified Acute Physiology Score 2 (SAPS 2) ${ }^{3}$ adalah model yang paling umum digunakan di seluruh dunia. Meskipun skor ini masih dapat menilai tingkat keparahan penyakit dalam uji klinis, kegunaannya untuk prediksi mortalitas telah 
dipertanyakan karena kurangnya performa prognostik dari waktu ke waktu, karena dikembangkan lebih dari 20 tahun yang lalu. Keterbatasan ini sangat penting karena obervasi rasio mortalitas telah menjadi standar untuk menilai luaran ICU dan merupakan indikator keselamatan dan kualitas yang harus diterapkan ICU untuk mengevaluasi kualitas layanan kesehatan ${ }^{4}$.

Pada tahun 2002, sekelompok peneliti di seluruh dunia mengumpulkan data baru tentang perubahan fisiologis, presentasi klinis dan hasil pasien kritis di lebih dari 300 ICU di seluruh dunia ${ }^{5}$. Data ini mengarah pada pengembangan model prognostik baru, SAPS $3^{6}$. Untuk pertama kalinya, model prediksi hasil umum mencakup data dari luar Eropa atau Amerika Serikat. Selain persamaan umum untuk estimasi kematian, SAPS 3 juga memberi pengguna akhir persamaan yang disesuaikan untuk tujuh wilayah berbeda di dunia, yang secara teoritis akan meningkatkan evaluasi kualitas perawatan dan benchmarking ${ }^{6}$.

Intensive Cardiovascular Care Unit (ICVCU) merupakan unit khusus yang merawat pasien dengan kegawatan kardiovaskular seperti sindrom koroner akut (SKA), gagal jantung akut, syok kardiogenik, aritmia yang mengancam nyawa, pasca intervensi kardiovaskular dengan komplikasi, emboli paru masif, pasca henti jantung, penyakit katup akut, diseksi aorta akut, dll 7 . SKA adalah salah satu alasan yang paling sering untuk masuknya pasien ke ICVCU ${ }^{8,9}$. Namun, presentasi klinis mereka bervariasi dan oleh karena itu, stratifikasi risiko bersifat fundamental untuk memandu pendekatan diagnostik dan terapeutik. Banyak skor prognostik spesifik telah dikembangkan dan divalidasi untuk pasien SKA. Diantaranya, Global Registry of Acute Coronary Events (GRACE) ${ }^{10}$ yang telah memiliki kinerja terbaik, mungkin karena desainnya yang sederhana, mengingat bahwa hal itu tidak membedakan antara pasien SKA dengan atau tanpa elevasi segmen ST. Namun untuk skor prognostik untuk menilai kegawatan kardiovaskuler secara keseluruhan belum pernah dikembangkan secara spesifik di populasi ICVCU.

Dokter ahli perawatan intensif biasanya menggunakan skor prognostik umum yang dikembangkan dari populasi heterogen pasien kritis, APACHE $^{11}$ dan SAPS ${ }^{12}$. Meskipun yang paling banyak digunakan versi awal dari skor ini, APACHE $2^{13}$ dan SAPS $2^{3}$, tidak memasukkan pasien SKA selama perkembangannya, versi terbaru mereka (APACHE
$4^{14}$ dan SAPS $3^{6}$ ) melakukan hal tersebut. Pada SAPS 3 sendiri disebutkan bahwa sekitar 6\% pasien masuk ICU dengan nyeri dada khas angina dengan EKG yang menunjukkan suatu SKA ${ }^{15}$. Sehingga dengan demikian, secara teori skor ini dapat digunakan untuk penilaian risiko pasien SKA di ICU umum.

Walaupun demikian, masih banyak subset penyakit kardiovaskular lain yang ada dalam populasi ICVCU yang juga berperan dalam mempengaruhi mortalitas selain SKA seperti syok kardiogenik, gagal jantung akut, penyakit vaskular akut dan lain-lain. Selain itu, populasi ICU pada umumnya terdapat pasien pasca operasi dimana hal ini tidak didapatkan pada populasi ICVCU dan hal ini tercantum dalam sistem skor prediktor. Dengan demikian, populasi pasien ICVCU pada dasarnya berbeda dengan populasi ICU umum bahkan dapat dikatakan sebagai populasi tersendiri. Sehingga sistem skor khusus di ICVCU diperlukan sebagai prediktor mortalitas pada populasi ini.

Namun, sebelum skor prediktor dapat diadopsi secara luas, mereka perlu divalidasi, yaitu kinerjanya harus dievaluasi dalam populasi yang berbeda dari keadaan dimana skor ini dikembangkan. Validasi ini dilakukan dengan mengevaluasi kalibrasi dan diskriminasi dari model ${ }^{16}$.

Penelitian ini mencoba melakukan evaluasi performa salah satu skor prediktor umum yaitu SAPS 3 terhadap pasien dengan kegawatan kardiovaskular. Pemilihan SAPS 3 pada penelitian ini didasari oleh karena skor ini lebih unggul dibanding skor lain karena hanya sistem skor ini yang dapat memprediksi mortalitas dalam waktu satu jam setelah masuk ICVCU. Selain keterlibatan pasien SKA pada populasi SAPS 3, beberapa variabelnya cukup lengkap yang dapat menggambarkan karakteristik dan kondisi pasien sebelum dan saat masuk unit rawat intensif serta mengevaluasi adanya perubahan fisiologis dan tingkat keparahannya saat masuk unit rawat intensif. Sehingga, sistem skor ini dapat menilai secara spesifik hubungan antara skor prediksi mortalitas dengan luaran pasien yang dirawat di ICVCU secara cepat dan komprehensif.

\section{Tujuan}

Penelitian ini bertujuan untuk mengevaluasi performa parameter skor SAPS 3 melalui uji kalibrasi dan diskriminasi pada populasi pasien kegawatan kardiovaskular yang dirawat di unit rawat intensif 
kardiovaskular (Intensive Cardiovascular Care Unit ICVCU) pada Pusat Jantung Nasional Harapan Kita (PJNHK) untuk dijadikan acuan prediktor mortalitas pasien.

\section{Metode}

\section{Desain dan Setting Penelitian}

Penelitian ini merupakan penelitian analitik dengan pendekatan potong lintang yang menggunakan data sekunder dari RAICOM (Registry of Acute and Intensive Cardiovascular Care on Outcome) yang dikumpulkan antara September 2013 - September 2014 pada ICVCU pada PJNHK. Unit ini merupakan unit yang menampung pasien kegawatan kardiovaskular dan pasca prosedur kardiologi invasif yang memerlukan perawatan intensif. Pasien dapat berasal dari unit gawat darurat, ruang rawat intermediate, bangsal perawatan dan ruang kateterisasi jantung.

\section{Pengumpulan dan Seleksi Data Penelitian}

Sampel penelitian merupakan data sekunder dari semua pasien yang terindikasi masuk ke ICVCU yang penilaiannya dilakukan oleh staf konsultan bidang intensive dan kegawatan kardiovaskuler dalam kurun waktu sebelum masuk ICVCU sampai satu jam setelah masuk ICVCU. Data ini kemudian secara manual dikumpulkan dan kemudian diseleksi sesuai dengan ketersediaan data dari variabel skor SAPS 3. Jika terdapat data yang tidak lengkap dan tidak valid maka data tersebut dieksklusi (lihat Gambar 1). Skor ini dibagi dalam 3 kotak. Kotak I merupakan data mengenai karakteristik pasien sebelum masuk ICU yang terdiri dari 5 variabel yaitu usia, komorbid, penggunaan vasokonstriktor sebelum masuk ICU, lokasi sebelum masuk ICU, dan lama rawat sebelum masuk ICU. Kotak II menjelaskan tentang kondisi saat masuk ICU yang terdiri dari 5 variabel yaitu alasan masuk ICU, perencanaan masuk ICU, status pembedahan, lokasi anatomis pembedahan dan ada tidaknya infeksi. Kotak III mengevaluasi mengenai ada tidaknya dan tingkat keparahan dari kelainan fisiologis saat masuk ICU (sebelum dan 1 jam sesudah admisi) yang mencakup 10 variabel antara lain Glasgow Coma Scale (GCS), denyut jantung, tekanan darah sistolik, bilirubin, suhu tubuh, kreatinin, leukosit, platelet, $\mathrm{pH}$, dan oksigenasi dan ventilasi mekanik6. Data-data ini kemudian disesuaikan dengan tabel skor SAPS 3 (lampiran 1) lalu dihitung untuk mendapatkan hasil akhir skor SAPS 3.

\section{Analisis Statistik}

Pengolahan data dan analisis statistik pada penelitian ini menggunakan SPSS versi 20.0. Seluruh karakteristik dasar disajikan dalam bentuk persentase kemudian dilakukan perhitungan skor SAPS 3. Lalu data tersebut dibagi dalam dua kelompok yaitu kelompok hidup dan kelompok meninggal yang kemudian masingmasing kelompok dilakukan evaluasi parameter skor SAPS 3. Uji statistik variabel data kategorik dilakukan dengan uji chi-square. Untuk data numerik dilakukan uji normalitas data Kolmogorov-Smirnov terlebih dahulu yang dilanjutkan dengan uji statistik independent t test jika sebaran data normal atau dengan uji Mann-Whitney jika sebaran data tidak normal. Performa prognostik SAPS 3 ini kemudian dianalisis dengan regresi logistik multivariat lalu dikalibrasi dengan menggunakan Hosmer-Lemeshow goodness-of-fit test yang mengevaluasi persetujuan antara jumlah yang terobservasi dan yang diharapkan pada pasien yang hidup dan yang meninggal terhadap seluruh tingkatan probabilitas kematian. Nilai $P$ yang tinggi $(\mathrm{P}>0.05)$ menunjukkan uji model yang baik $^{17}$. Untuk uji diskriminasi skor dilakukan dengan menilai area under the receiver operating characteristic curve (AUC) dan 95\% confidence interval (CI). Jika nilai diskriminasi 0.9-0.99 dianggap paling baik, 0.8-0.89 sangat baik, 0.7-0.79 baik, 0.6-0.69 sedang, dan $<0.6$ kurang baik ${ }^{18}$.

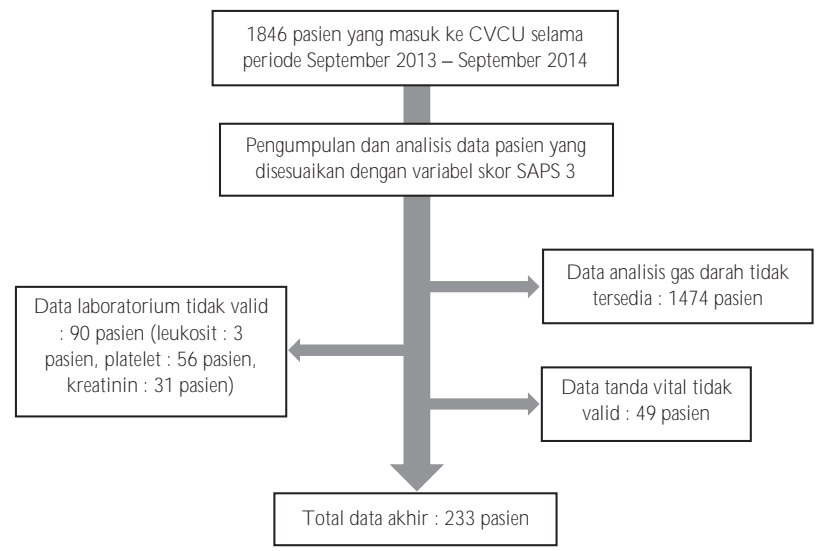

Gambar 1 : Alur seleksi data sekunder sesuai variabel skor SAPS 3 


\section{Hasil}

Data sekunder yang diperoleh selama rentang waktu penelitian berjumlah 1846 pasien. Data ini kemudian diolah dan diseleksi berdasarkan ketersediaan dan kelengkapan data yang disesuaikan dengan variabel SAPS 3 yang akhirnya didapatkan total 233 data pasien saja yang dipakai untuk penelitian ini.

Mengingat SAPS 3 ini dikembangkan di populasi ICU umum, terdapat beberapa variabel skor SAPS yang parameternya sedikit dimodifikasi. Lokasi rawat sebelum masuk CVCU yang seharusnya terdiri dari Ruang Operasi, UGD, ICU lain, dan Ruangan lain diubah menjadi UGD, Intermediate Ward (IW), Cathlab dan Ruang Rawat Biasa. Selain itu, parameter komorbiditas yang dimasukkan hanya gagal jantung kronik. Lalu, alasan masuk ICVCU juga disesuaikan dengan indikasi pasien tersebut masuk ICVCU antara lain SKA, aritmia, post prosedural intervensi kardiovaskular, gagal napas, dan syok. Untuk variabel perencanaan masuk unit rawat intesif juga disesuaikan yang mana kriteria masuk ICVCU terencana hanya pasien pasca prosedural intervensi vaskular elektif. Semua parameter yang dimodifikasi ini dilakukan penyesuaian poin berdasarkan definisi data SAPS 3. Untuk variabel status pembedahan dan lokasi anatomis pembedahan tidak dimasukkan oleh karena memang populasi pasien ICVCU tidak termasuk pasien pasca pembedahan kardiovaskular.

Rata-rata usia pasien berkisar antara 59,8 tahun. Rentang usia 40-59 tahun merupakan rentang usia yang memiliki frekuensi terbanyak yaitu sebesar $45.5 \%$ dari total 233 pasien. Hampir seluruh pasien yaitu 230 orang $(98,7 \%)$ memiliki lama rawat sebelum masuk ICVCU kurang dari 14 hari dengan rata-rata lama rawat 1,3 hari. Terdapat $73 \%$ pasien masuk dengan CHF. Sindroma koroner akut merupakan alasan yang paling sering pasien masuk ke ICVCU diikuti aritmia dan syok dengan masing-masing persentase sebesar $55.8 \%, 20.6 \%$, dan $17.2 \%$. Hampir seluruh pasien yang masuk CVCU merupakan pasien yang tidak terencana yaitu sekitar 99.2\%, sedangkan yang terencana hanya sebesar $0.8 \%$ dimana pasien ini merupakan pasien pasca prosedural vaskular elektif. Oleh karena seluruh pasien merupakan pasien ICVCU, maka tidak ada variabel status pembedahan dan lokasi anatomis pembedahan. Sementara itu, lebih dari setengah jumlah total pasien yaitu $63.9 \%$ (149 orang) tidak mengalami infeksi, namun demikian, infeksi dalam bentuk pneumonia yaitu community-acquired pneumonia (CAP) dan hospital-acquired pneumonia (HAP) terjadi pada $28.8 \%$ (67 orang) dan $7.3 \%$ (17 orang) secara berurutan.

Penilaian kelainan fisiologis pasien yang masuk ke CVCU dilakukan dengan melihat beberapa faktor. Tingkat kesadaran dinilai dengan Glasgow Coma Scale (GCS) yang menunjukkan angka GCS rata-rata 13,93. Suhu badan rata-rata semua pasien adalah 36,03 derajat Celcius. Tekanan darah sistolik rata-rata pasien adalah $121,81 \mathrm{mmHg}$ sedangkan denyut jantung ratarata adalah 97,8 kali per menit. Data laboratorium pasien juga diambil untuk menilai adanya kelainan fisiologis. Seluruh pasien memiliki kadar bilirubin yang normal $(<2 \mathrm{mg} / \mathrm{dL})$. Profil sel darah yang dinilai pada skor ini adalah leukosit dan platelet yang kadar rata-ratanya adalah $13.335,3 \mathrm{uL}$ dan 247.983,39 uL secara berurutan. Fungsi ginjal dinilai dengan kreatinin dimana didapatkan nilai rata-rata $1,98 \mathrm{mg} / \mathrm{dL}$. Analisa gas darah menunjukkan $\mathrm{pH}$ rata-rata 7,37 dengan $\mathrm{pO} 2$ $123,66 \mathrm{mmHg}$. Dari total keseluruhan pasien terdapat 72 pasien $(30,9 \%)$ yang diberikan ventilasi mekanik dimana terdapat 49 orang (21\%) memiliki rasio $\mathrm{PaO} 2 /$ FiO2 yang lebih dari 100 dan yang kurang dari 100 sebanyak 23 orang $(9,9 \%)$.

Hasil analisis statistik bivariat luaran pasien didapatkan bahwa dari 233 sampel, terdapat 194 orang $(83,26 \%)$ yang hidup dan 39 orang $(16,74 \%)$ meninggal. Dari 20 variabel skor SAPS 3, terdapat 7 variabel yang secara statistik berbeda bermakna $(\mathrm{p}<0,05)$ dalam menilai mortalitas (lihat Tabel 1). Lokasi unit rawat sebelum masuk ICVCU memiliki perbedaan yang bermakna $(\mathrm{p}=0,002)$ dengan angka terbesar kematian berasal dari UGD yaitu 21 orang dari 39 orang yang meninggal atau sebesar 53,8\%. Sementara itu, dari 20 pasien yang menggunakan obat vasoaktif, sebagian besar pasien hidup dengan persentase $60 \%$ dengan hasil analisis yang signifikan $(\mathrm{p}=0,004)$. Variabel alasan masuk ICVCU memiliki perbedaan yang bermakna $(\mathrm{p}<0,0001)$ dimana alasan kondisi syok memiliki persentase terbesar terhadap kematian di ICVCU yaitu $38,6 \%$ atau 15 dari 39 orang. Infeksi juga merupakan faktor yang memiliki perbedaan bermakna $(\mathrm{p}=0,018)$ namun persentasi kematian terbesar $(82,1 \%)$ merupakan pasien yang tanpa infeksi. Rata-rata tingkat kesadaran (GCS) pasien yang bertahan hidup adalah 
Tabel 1 : Distribusi karakteristik variabel skor SAPS 3

\begin{tabular}{|c|c|c|c|}
\hline Variabel Skor & Hidup $(n=194)$ & Meninggal $(n=39)$ & $\mathrm{P}$ \\
\hline $\begin{array}{l}\text { Usia [tahun - mean] } \\
\quad<40 \text { tahun }[\mathrm{n}(\%)] \\
40-59 \text { tahun }[\mathrm{n}(\%)] \\
60-69 \text { tahun }[\mathrm{n}(\%)] \\
70-74 \text { tahun }[\mathrm{n}(\%)] \\
75-79 \text { tahun }[\mathrm{n}(\%)] \\
\geq 80 \text { tahun }[\mathrm{n}(\%)]\end{array}$ & $\begin{array}{c}59,89 \\
9 / 194(4,6) \\
87 / 194(44,8) \\
60 / 194(30,9) \\
15 / 194(7,7) \\
19 / 194(9,7) \\
4 / 194(2,0)\end{array}$ & $\begin{array}{c}59,36 \\
2 / 39(5,1) \\
19 / 39(48,7) \\
8 / 39(20,5) \\
6 / 39(15,3) \\
1 / 39(2,5) \\
3 / 39(7,6)\end{array}$ & 0,681 \\
\hline Lama Rawat Sebelum Masuk CVCU (hari - mean) & 1,15 & 2,00 & 0,091 \\
\hline $\begin{array}{l}\text { Lokasi Sebelum Masuk CVCU } \\
\text { Unit Gawat Darurat (UGD) [n(\%)] } \\
\text { Intermediate Ward (IW)[n(\%)] } \\
\text { Cath Lab [n(\%)] } \\
\text { Ruang Rawat Biasa [n(\%)] }\end{array}$ & $\begin{array}{c}117 / 194(60,3) \\
13 / 194(6,7) \\
58 / 194(29,8) \\
6 / 194(3,0)\end{array}$ & $\begin{array}{c}21 / 39(53,8) \\
10 / 39(25,6) \\
6 / 39(15,3) \\
2 / 39(5,1)\end{array}$ & 0,002 \\
\hline $\begin{array}{l}\mathrm{CHF}[\mathrm{n}(\%)] \\
\quad \text { Ada }[\mathrm{n}(\%)] \\
\text { Tidak Ada }[\mathrm{n}(\%)]\end{array}$ & $\begin{array}{c}138 / 170(81,2) \\
56 / 63(88,9)\end{array}$ & $\begin{array}{c}32 / 170(18,8) \\
7 / 63(11,1)\end{array}$ & 0,161 \\
\hline $\begin{array}{l}\text { Penggunaan Obat Vasoaktif }[\mathrm{n}(\%)] \\
\text { Ya }[\mathrm{n}(\%)] \\
\text { Tidak }[\mathrm{n}(\%)]\end{array}$ & $\begin{array}{c}12 / 20(60) \\
182 / 213(85,4)\end{array}$ & $\begin{array}{c}8 / 20(40) \\
31 / 213(14,6)\end{array}$ & 0,004 \\
\hline $\begin{array}{l}\text { Perencanaan Masuk CVCU } \\
\text { Terencana }[\mathrm{n}(\%)] \\
\text { Tidak Terencana }[\mathrm{n}(\%)]\end{array}$ & $\begin{array}{c}2 / 2(100) \\
192 / 231(83,2)\end{array}$ & $\begin{array}{c}0 / 2(0) \\
39 / 231(16,8)\end{array}$ & 0,266 \\
\hline $\begin{array}{l}\text { Alasan Masuk CVCU } \\
\text { ACS [n(\%)] } \\
\text { Aritmia [n(\%)] } \\
\text { Post Prosedural }[\mathrm{n}(\%)] \\
\text { Gagal Napas }[\mathrm{n}(\%)] \\
\text { Syok }[\mathrm{n}(\%)]\end{array}$ & $\begin{array}{l}118 / 194(60,8) \\
36 / 194(18,6) \\
2 / 194(1,0) \\
13 / 194(6,7) \\
25 / 194(12,9)\end{array}$ & $\begin{array}{c}12 / 39(30,7) \\
12 / 39(30,7) \\
0 / 39(0) \\
0 / 39(0) \\
15 / 39(38,6)\end{array}$ & $<0,0001$ \\
\hline Status Pembedahan $[\mathrm{n}(\%)]$ & - & - & - \\
\hline Lokasi Anatomis Pembedahan [n(\%)] & - & - & - \\
\hline $\begin{array}{l}\text { Infeksi } \\
\qquad \text { CAP }[\mathrm{n}(\%)] \\
\text { HAP [n(\%)] } \\
\text { Tanpa Infeksi }[\mathrm{n}(\%)]\end{array}$ & $\begin{array}{c}63 / 194(32,5) \\
14 / 194(7,2) \\
117 / 194(60,3)\end{array}$ & $\begin{array}{c}4 / 39(10,2) \\
3 / 39(7,7) \\
32 / 39(82,1)\end{array}$ & 0,018 \\
\hline Tingkat Kesadaran [GCS - mean] & 14,16 & 12,77 & 0,038 \\
\hline Bilirubin $[\mathrm{mg} / \mathrm{dL}]$ & $<2$ & $<2$ & - \\
\hline Suhu Tubuh [derajat Celcius - mean] & 36,03 & 36,07 & 0,332 \\
\hline Kreatinin [mg/dL - mean] & 1,94 & 2,13 & 0,021 \\
\hline Denyut Jantung $[\mathrm{x} /$ menit- mean $]$ & 99,51 & 89,31 & 0,058 \\
\hline Leukosit [uL - mean] & 13127,04 & 14371,28 & 0,41 \\
\hline $\mathrm{pH}[$ mean] & 7,38 & 7,36 & 0,276 \\
\hline Platelet [uL - mean] & 254588,30 & 215128,21 & 0,046 \\
\hline Tekanan Darah Sistolik [mmHg - mean] & 122,30 & 119,36 & 0,551 \\
\hline $\begin{array}{l}\text { Profil Ventilasi Mekanik (VM) } \\
\text { PO2 [mmHg - mean] } \\
\text { Ventilasi Mekanik }[\mathrm{n}(\%)] \\
\mathrm{PaO} 2>=60 \text { dan tanpa VM }[\mathrm{n}(\%)] \\
\mathrm{PaO} 2<60 \text { dan tanpa VM }[\mathrm{n}(\%)] \\
\mathrm{PaO} 2 / \mathrm{FiO} 2>=100 \text { dengan } \mathrm{VM}[\mathrm{n}(\%)] \\
\mathrm{PaO} 2 / \mathrm{FiO} 2<100 \text { dengan } \mathrm{VM}[\mathrm{n}(\%)]\end{array}$ & $\begin{array}{c}122,51 \\
58 / 72(80,5) \\
130 / 194(67) \\
6 / 194(3,1) \\
37 / 194(19) \\
21 / 194(10,9)\end{array}$ & $\begin{aligned} & 129,41 \\
& 14 / 72(19,5) \\
& 24 / 39(61,5) \\
& 1 / 39(2,6) \\
& 12 / 39(30,7) \\
& 2 / 39(5,2)\end{aligned}$ & $\begin{array}{l}0,35 \\
0,459 \\
\mathrm{n} / \mathrm{a} \\
\mathrm{n} / \mathrm{a} \\
\mathrm{n} / \mathrm{a} \\
\mathrm{n} / \mathrm{a}\end{array}$ \\
\hline Skor SAPS 3 [mean] & 49 & 66 & $<0,0001$ \\
\hline
\end{tabular}


sebesar 14,16 dan yang meninggal adalah sebesar 12,77 dengan nilai p yang signifikan yaitu 0,038 . Selain itu kadar kreatinin pasien juga memiliki perbedaan yang bermakna $(\mathrm{p}=0,021)$ dengan kadar kreatinin rata-rata pasien yang hidup dan meninggal sebesar $1,94 \mathrm{mg} / \mathrm{dL}$ dan $2,13 \mathrm{mg} / \mathrm{dL}$ secara berturut-turut. Begitu pula pada kadar platelet didapatkan hasil yang berbeda signifikan ( $\mathrm{p}=0,046)$ dengan kadar rata-rata masing pasien yang hidup dan meninggal sebesar 254588,30 uL dan 215128,21 uL. Setelah dilakukan perhitungan skor SAPS 3, didapatkan hasil rata-rata skor untuk pasien yang hidup sebesar 49 poin, sedangkan yang meninggal sebesar 66 poin dengan nilai p yang sangat signifikan yaitu $<0,0001$.

Analisis bivariat dilakukan terhadap 20 variabel SAPS 3 dan didapatkan 9 variabel yang layak diuji multivariat (lihat tabel 2) untuk menilai faktor mana yang berhubungan erat secara independen dengan mortalitas ICVCU. Variabel penggunaan obat vasoaktif, pasien tanpa infeksi, pasien dengan CAP, pasien dengan lama rawat sebelum masuk ICVCU 14-28 hari, kadar platelet $>100.000 \mathrm{uL}$, kadar platelet 20.000-50.000 uL, UGD sebagai lokasi rawat sebelum masuk ICVCU, dan IW sebagai lokasi rawat sebelum masuk ICVCU adalah faktor-faktor yang ternyata berhubungan erat dengan mortalitas ICVCU dengan $\mathrm{p}<0,05$.

Uji kalibrasi SAPS 3 dengan Hosmer-Lemeshow goodness-of-fit test menunjukkan hasil yang baik dengan $\mathrm{p}=0,943$ (lihat tabel 3). Selain itu, penilaian AUC, yang ditunjukkan oleh Tabel 4, memperlihatkan bahwa SAPS 3 memiliki kemampuan diskriminasi dalam menentukan mortalitas dengan baik $[0,752(0,669$ $0,835)]$.

Hasil analisis ini kemudian dilanjutkan dengan analisis regresi logistik multivariat untuk menilai faktor yang berhubungan secara independen terhadap mortalitas (lihat tabel 5). Analisis tersebut menunjukkan hasil yang sangat menarik dimana ternyata pasien dengan CAP secara independen berhubungan dengan kesintasan pasien dengan $\mathrm{OR}=0,224 ; 95 \%$ CI 0,068 - 0,730; $\mathrm{p}=0,013$. Sedangkan faktor yang paling berpengaruh dalam meningkatkan mortalitas ICVCU secara independen adalah pasien yang dirawat di IW sebelum masuk ICVCU dengan OR=4,165; 95\% CI 1,462 - 11,864; $\mathrm{p}=0,008$. Sehingga dapat dikatakan bahwa pasien dengan CAP sebagai faktor protektif terhadap kematian, sedangkan lokasi rawat IW sebelum masuk ICVCU merupakan faktor risiko mortalitas pasien.

\section{Diskusi}

Le Gall dan rekannya mengembangkan skor SAPS dengan cara menyederhanakan APACHE. Simplified Acute Physiology Score yang dikembangkan dan divalidasi di Prancis pada tahun 1984 ini, menggunakan 13 variabel fisiologis terukur dan usia untuk memprediksi risiko kematian pada pasien ICU. Seperti nilai APACHE, SAPS dihitung dari nilai terburuk yang diperoleh selama 24 jam pertama penerimaan di ICU. Pada tahun 1993, mereka ${ }^{19}$ menggunakan analisis regresi logistik untuk mengembangkan SAPS 2, yang mencakup 17 variabel yaitu 12 variabel fisiologis, usia, jenis masuk, dan 3 variabel yang terkait dengan penyakit yang dasar. Skor SAPS 2 divalidasi dengan menggunakan data konsekutif dari 137 ICU di 12 negara ${ }^{19}$. Dari data-data sebelumnya ini, akhirnya pada tahun 2005, dibentuklah model SAPS baru yaitu SAPS 3. Skor SAPS 3 mencakup 20 variabel dibagi menjadi tiga sub skor yang terkait dengan karakteristik pasien sebelum masuk, keadaan masuk, dan tingkat gangguan psikologis dalam 1 jam (berbeda dengan window period 24 jam pada model SAPS II) sebelum atau sesudah masuk ICU. Skor total bisa berkisar antara 0 sampai 217. Tidak seperti nilai lainnya, SAPS 3 menyertakan persamaan yang disesuaikan untuk prediksi mortalitas di tujuh wilayah geografis: Australasia; Amerika Tengah dan Selatan; Tengah, Eropa Barat; Eropa Timur; Eropa Utara; Eropa Selatan, Mediterania; dan Amerika Utara ${ }^{3}$.

Pada penelitian ini, terdapat beberapa parameter SAPS 3 yang berhubungan dengan mortalitas yang menunjukkan perbedaan yang signifikan dalam hal

Tabel 3 : Uji Kalibrasi Hosmer-Lemeshow

\begin{tabular}{ccc}
\hline \multicolumn{3}{c}{ H-L Test } \\
\hline Chi-square & $\mathrm{df}$ & $\mathrm{p}^{*}$ \\
\hline 6,279 & 8 & 0,616 \\
7,102 & 8 & 0,526 \\
2,783 & 7 & 0,904 \\
4,092 & 6 & 0,664 \\
1,729 & 6 & 0,943 \\
\hline
\end{tabular}

${ }^{*}$ Kalibrasi baik jika $\mathrm{p}>0.05$ 
mortalitas antara lain alasan masuk ICVCU, lokasi pasien sebelum masuk ICVCU, penggunaan agen vasoaktif, ada tidaknya infeksi, tingkat kesadaran, kadar kreatinin dan jumlah platelet.

Seperti yang telah diterangkan sebelumnya, studi mengenai skor prediksi kematian belum secara luas diteliti pada populasi khusus seperti di CVCU. Namun adanya studi skor prediksi yang sudah mencakup

Tabel 2 : Analisis bivariat faktor yang berkaitan dengan mortalitas

\begin{tabular}{lccc}
\hline \multicolumn{1}{c}{ Variabel } & Score & $\mathrm{df}$ & $\mathrm{P}$ \\
\hline CHF & 1,962 & 1 & 0,161 \\
Penggunaan Obat Vasoaktif & 8,495 & 1 & $0,004^{*}$ \\
Infeksi & & & \\
$\quad$ Tanpa Infeksi & 7,985 & 2 & $0,018^{*}$ \\
$\quad$ CAP & 7,824 & 1 & $0,005^{*}$ \\
$\quad$ HAP & 0,011 & 1 & 0,917 \\
Lama rawat Sebelum Masuk & 5,436 & 1 & $0,020^{*}$
\end{tabular}

CVCU 14-28 hari

Platelet

$>100.000 \mathrm{uL}$

50.000-100.000 uL

20.000-50.000 uL

Tekanan Darah Sistolik

$\begin{array}{llll}>120 \mathrm{mmHg} & 1,438 & 2 & 0,487 \\ 70-120 \mathrm{mmHg} & 1,306 & 1 & 0,253 \\ 40-70 \mathrm{mmHg} & 0,039 & 1 & 0,843\end{array}$

Lokasi Rawat Sebelum Masuk

$\begin{array}{lccc}\text { CVCU } & 14,911 & 3 & 0,002^{*} \\ \text { UGD } & 3,433 & 1 & 0,064 \\ \text { Cathlab } & 13,093 & 1 & 0,000^{*} \\ \text { Intermediate Ward (IW) } & 0,406 & 1 & 0,524 \\ \quad \text { Ruang Rawat Biasa } & & & \\ \text { Kreatinin } & & & \\ <1,2 \mathrm{mg} / \mathrm{dL} & 6,135 & 3 & 0,105 \\ 1,2-2 \mathrm{mg} / \mathrm{dL} & 0,760 & 1 & 0,383 \\ 2-3,5 \mathrm{mg} / \mathrm{dL} & 1,607 & 1 & 0,205 \\ >3,5 \mathrm{mg} / \mathrm{dL} & 0,458 & 1 & 0,499 \\ \text { Denyut Jantung } & & & \\ <120 \mathrm{x} / \mathrm{mnt} & 3,980 & 2 & 0,137 \\ 120-160 \mathrm{x} / \mathrm{mnt} & 3,591 & 1 & 0,058 \\ >160 \mathrm{x} / \mathrm{mnt} & 0,213 & 1 & 0,645\end{array}$

*faktor signifikan yang berkaitan dengan mortalitas $(\mathrm{p}<0.05)$ pasien sindroma koroner akut (1200 pasien dari total 19577 pasien atau 6,13\%) ${ }^{15}$ pada populasinya seperti pada SAPS $3^{3}$ ini, sedikit banyak dapat mencerminkan prediksi mortalitas apalagi memang sebagian besar pasien yang masuk ke CVCU adalah pasien SKA. Hal ini diperlihatkan oleh hasil studi kami yang menunjukkan lebih dari setengah pasien yang masuk dan dirawat di CVCU merupakan pasien SKA. Walaupun demikian berdasarkan hasil analisis kami, ada beberapa kondisi masuk CVCU selain SKA yang patut diperhitungkan dalam menilai persentase kematian. Analisis statistik univariat pada variabel ini menunjukkan nilai yang sangat signifikan $(\mathrm{P}<0,0001)$ dalam hubungannya dengan mortalitas. Pasien yang masuk sudah dengan kondisi syok merupakan pasien yang memiliki persentase mortalitas terbesar dibandingkan dengan alasan yang lain yaitu 15 orang dari total 39 orang atau $38,6 \%$. Jika dilihat lebih detail dari subset data kematian

Tabel 4 : AUC SAPS 3

\begin{tabular}{ccccc}
\hline \multicolumn{4}{c}{ Area Under the Curve } \\
\hline Test Result Variable(s): & & \multicolumn{2}{c}{ Asymptotic 95\% } \\
\hline & & Confidence Interval \\
\cline { 3 - 5 } Area* $^{*}$ & Std. Error & $\begin{array}{c}\text { Asymptoti c } \\
\text { Sig. }\end{array}$ & $\begin{array}{c}\text { Lower } \\
\text { Bound }\end{array}$ & $\begin{array}{c}\text { Upper } \\
\text { Bound }\end{array}$ \\
\hline 0,752 & 0,042 & 0,000 & 0,669 & 0,835 \\
\hline
\end{tabular}

a. Under the nonparametric assumption

b. Null hypothesis: true area $=0.5$

*0.9-0.99 paling baik; 0.8-0.89 sangat baik; 0.7-0.79 baik; $0.6-0.69$ sedang; dan $<0.6$ kurang baik

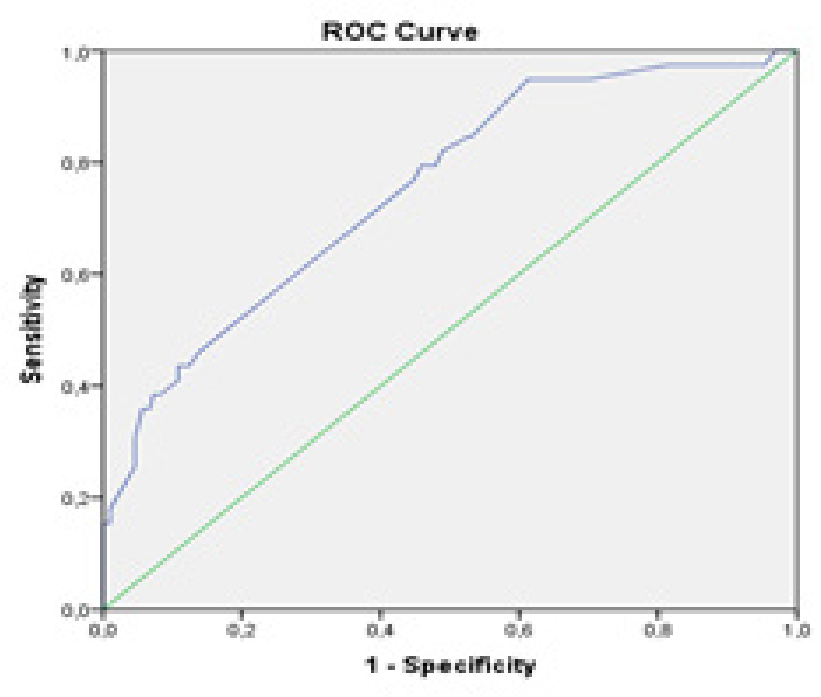

Diagenal segments ane profuced by ties 
Indonesian Journal of Cardiology

Tabel 5 : Analisis regresi logistik multivariat SAPS 3

\begin{tabular}{|c|c|c|c|c|c|c|c|c|}
\hline \multirow{2}{*}{ Variabel } & \multirow{2}{*}{ B } & \multirow{2}{*}{ SE } & \multirow{2}{*}{ Wald } & \multirow{2}{*}{ df } & \multirow{2}{*}{$\mathrm{p}$} & \multirow{2}{*}{ OR } & \multicolumn{2}{|c|}{$95 \% \mathrm{CI}$} \\
\hline & & & & & & & Lower & Upper \\
\hline Penggunaan Obat Vasoaktif & 1,008 & 0,567 & 3,159 & 1 & 0,075 & 2,741 & 0,902 & 8,334 \\
\hline \multicolumn{9}{|l|}{ Infeksi } \\
\hline Tanpa Infeksi & & & 6,300 & 2 & 0,043 & & & \\
\hline CAP & $-1,498$ & 0,604 & 6,160 & 1 & 0,013 & 0,224 & 0,068 & 0,730 \\
\hline HAP & 0,029 & 0,715 & 0,002 & 1 & 0,967 & 1,030 & 0,253 & 4,185 \\
\hline \multicolumn{9}{|l|}{ Platelet } \\
\hline$>100.000 \mathrm{uL}$ & & & 3,049 & 2 & 0,218 & & & \\
\hline $50.000-100.000 \mathrm{uL}$ & 1,354 & 0,775 & 3,049 & 1 & 0,081 & 3,872 & 0,847 & 17,69 \\
\hline $20.000-50.000 \mathrm{uL}$ & 22,794 & 40192,9 & 0,000 & 1 & 1,000 & 7928860659,3 & 0,000 & \\
\hline \multirow{2}{*}{\multicolumn{9}{|c|}{$\begin{array}{l}\text { Lokasi Rawat Sebelum Masuk } \\
\text { CVCU }\end{array}$}} \\
\hline & & & & & & & & \\
\hline UGD & & & 8,466 & 3 & 0,037 & & & \\
\hline Cathlab & $-0,217$ & 0,528 & 0,169 & 1 & 0,681 & 0,805 & 0,286 & 2,264 \\
\hline Intermediate & 1,427 & 0,534 & 7,134 & 1 & 0,008 & 4,165 & 1,462 & 11,86 \\
\hline Ruang Rawat Biasa & 0,506 & 0,864 & 0,343 & 1 & 0,558 & 1,659 & 0,305 & 9,016 \\
\hline \multicolumn{9}{|l|}{ Denyut Jantung } \\
\hline$<120 \mathrm{x} / \mathrm{mnt}$ & & & 3,421 & 2 & 0,181 & & & \\
\hline $120-160 \mathrm{x} / \mathrm{mnt}$ & $-1,460$ & 0,790 & 3,413 & 1 & 0,065 & 0,232 & 0,049 & \\
\hline$>160 \mathrm{x} / \mathrm{mnt}$ & 0,019 & 1,113 & 0,000 & 1 & 0,987 & 1,019 & 0,115 & \\
\hline
\end{tabular}

SE: standard error; OR : odds ratio; CI : confidence interval; CAP : community-acquired pneumonia; HAP : hospital-acquired pneumonia

ini, terdapat $60 \%$ atau 9 dari 15 orang tersebut yang penyebab kematiannya juga oleh karena syok dimana syok kardiogenik sebanyak 6 orang $(67 \%)$ dan syok sepsis sebanyak 3 orang (33\%). Hal ini sejalan dengan hasil dari SHOCK Registry yang memperlihatkan mortalitas keseluruhan pasien dengan syok kardiogenik sebesar $66 \%{ }^{20}$

Penggunaan obat vasoaktif merupakan hal yang umum dilakukan pada perawatan intensif termasuk ICVCU. Obat vasoaktif paling sering digunakan antara lain epinefrin, norepinefrin, dobutamin, dopamin, dan milrinon. Pada beberapa pasien terutama yang mengalami syok sirkulasi yang berat, kombinasi antara obat-obat ini menjadi hal sering dijumpai. Suatu penelitian multinasional CardShock Study pada 216 pasien syok kardiogenik menunjukkan peningkatan mortalitas 90 hari sebesar $41 \%$. Penelitian tersebut juga mengatakan bahwa penggunaan obat vasoaktif epinefrin secara independen dapat meningkatkan mortalitas 90 hari (OR 5.2, 95 \% CI 1.88, 14.7, $\mathrm{p}=0.002) 21$. Pada penelitian kami, obat vasoaktif dobutamin dan norepinefrin merupakan obat yang paling sering digunakan, baik secara tunggal maupun kombinasi, disamping penggunaan dopamine dan milrinone. Penggunaan obat vasoaktif ini memiliki hubungan erat dengan mortalitas $(p=0,004)$ dengan persentase kematian $40 \%$ pada pasien pengguna obat vasoaktif. Walaupun demikian, setelah dianalisis lebih lanjut dengan regresi logistik ternyata penggunaan obat vasoaktif tidak memiliki pengaruh secara independen terhadap mortalitas.

Walaupun subset pasien yang masuk ke ICVCU sebagian besar adalah SKA, namun tidak semua pasien berasal dari cathlab atau dengan kata lain pasien yang menjalani intervensi koroner perkutan (IKP) primer sebagai manajemen awal infark miokard akut dengan ST elevasi (IMA-STE). Pasien yang berasal dari UGD memiliki proporsi terbesar $(59,2 \%)$ yang artinya jumlah ini terdiri dari pasien-pasien yang selain pasien IMASTE yang terindikasi IKP primer dan dapat dijadikan standar lokasi sebelum masuk CVCU. Hubungan lokasi rawat sebelum masuk ICVCU dengan mortalitas memiliki hubungan erat dengan angka signifikan $(\mathrm{p}=0,002)$ sehingga dapat dikatakan bahwa lokasi rawat sebelum masuk ICVCU merupakan salah satu penentu mortalitas. Menariknya, dengan analisis regresi logistik multivariat, didapatkan bahwa lokasi rawat IW sebelum ICVCU merupakan faktor risiko independen 
mortalitas atau dengan kata lain pasien yang berasal dari IW memiliki probabilitas 4,165 kali lebih besar kejadian mortalitas dibandingkan dengan standar. Hal ini mungkin dapat dijelaskan dengan suatu pemikiran bahwa semua pasien yang sebelumnya dirawat di IW dan akhirnya masuk ke ICVCU adalah pasien-pasien yang terjadi perburukan kondisi klinis. Secara spekulatif, perburukan kondisi bisa terjadi oleh karena adanya perbedaan tingkat intensitas perawatan di IW dengan ICVCU atau dapat juga oleh karena sifat perjalanan penyakit tersebut yang tidak dapat dihindari ataupun kedua faktor ini yang saling berhubungan satu sama lain.

Infeksi dalam bentuk pneumonia baik CAP maupun HAP merupakan salah satu masalah yang sering kita hadapi dalam perawatan intensif. Penelitian oleh Corrales-Medina bersama rekannya menunjukkan bahwa terjadinya komplikasi kardiovaskular pada pasien dengan CAP berhubungan dengan peningkatan 60\% risiko kematian dalam 30 hari $(\mathrm{OR}=1,6$; $95 \% \mathrm{CI}$ : 1,042,5; $\mathrm{P}=0,03) 22$. Pada penelitian kami, sebagian besar pasien tidak mengalami infeksi. Analisis statistik bivariat menunjukkan bahwa keterlibatan infeksi memiliki hubungan erat dengan mortalitas $(\mathrm{p}=0,018)$. Namun demikian, ada hal yang sangat menarik dan berbeda dengan penelitian lain setelah data tersebut dianalisis secara regresi logistik multivariat yang menunjukkan bahwa pasien dengan komorbid CAP memiliki sifat protektif terhadap kematian. Hal ini mungkin dapat terjadi oleh karena data pasien infeksi dan non-infeksi yang tidak berimbang dalam penelitian ini. Penjelasan lain mengenai fenomena ini mungkin juga dapat mengacu pada terapi antibiotik empirik yang dimulai secara langsung saat masuk CVCU bahkan mungkin sebelum masuk CVCU meskipun data mengenai waktu dimulainya pemberian antibiotik tidak diambil pada penelitian ini. Inisiasi dini pemberian antibiotik dapat mempercepat eradikasi kuman patogen untuk mencegah perburukan infeksi seperti sepsis dan syok septik yang mempengaruhi mortalitas CVCU. Hal ini sejalan dengan studi retrospektif pada 13.771 pasien dengan CAP yang menunjukkan bahwa pemberian antibiotik dalam waktu empat jam dari kedatangan pasien di UGD berhubungan dengan penurunan mortalitas $(6.8 \%$ dibandingkan $7.4 \%$ pada pasien dengan penundaan pemberian antibiotik)23. Infectious Diseases Society of America dan American Thoracic
Society merekomendasikan pemberian antibiotik sesegera mungkin dimulai saat diagnosis CAP telah ditegakkan dan sebelum pasien tersebut dipindahkan dari UGD24. Begitu pula jika pasien yang sudah datang dengan sepsis yang mana rekomendasi Surviving Sepsis Campaign 2016 menyatakan bahwa pemberian antibiotik intravena sebaiknya dimulai secepat mungkin setelah diagnosis sepsis atau syok septik ditegakkan25.

Pada penelitian ini, jumlah skor SAPS 3 didapatkan lebih tinggi secara signifikan pada pasien yang meninggal dibandingkan pasien hidup sehingga dapat disimpulkan bahwa semakin tinggi skor maka akan semakin tinggi mortalitas. SAPS 3 juga menunjukkan diskriminasi yang baik dari AUC (0,752). Performa SAPS 3 juga didukung oleh uji kalibrasi dengan analisis statistik Hosmer-Lemeshow goodness-of-fit yang menunjukkan kalibrasi yang baik dengan $\mathrm{p}=0,943$. Dari hasil ini, dapat disimpulkan bahwa SAPS 3 dapat menentukan pasien yang memiliki risiko mortalitas pada populasi ICVCU.

Penelitian ini memiliki sejumlah keterbatasan khususnya dalam hal ketersediaan dan kelengkapan data. Pertama, jumlah sampel yang sangat sedikit jika dibandingkan dengan jumlah total pasien yang dirawat di ICVCU selama periode 12 bulan oleh karena banyaknya sampel dengan data yang tidak lengkap. Hal ini merupakan salah satu keterbatasan yang dapat diatasi di masa yang akan datang dengan menggunakan data primer yang sudah disesuaikan dengan variabel skor SAPS 3. Kedua, penelitian ini juga tidak meneliti subgrup berdasarkan diagnosis masuk ICVCU yang dapat memudahkan kita untuk menilai dan memprediksi mortalitas masingmasing jenis penyakit yang sering dirawat di unit ini. Ketiga, tidak dilakukannya validasi eksternal dengan membandingkan populasi ICVCU dengan ICU umum yang mana akan lebih dapat meyakinkan performa skor prediksi mortalitas pada populasi pasien yang dirawat di ICVCU sehingga hal ini perlu diterapkan dalam penelitian-penelitian selanjutnya. Walaupun penelitian ini menunjukkan hasil yang baik, namun peluang untuk merumuskan dan mengembangkan skor baru yang ideal untuk populasi pasien dengan kegawatan kardiovaskular masih sangat luas khususnya untuk data-data pendukung kardiovaskular lainnya seperti biomarker jantung, fungsi jantung dan hemodinamik secara ekokardiografi, dan parameter lainnya yang 
dianggap perlu dan sering digunakan dalam tatalaksana pasien kegawatan kardiovaskular.

\section{Kesimpulan}

Penilitian ini menyimpulkan bahwa peningkatan skor SAPS 3 berhubungan dengan peningkatan mortalitas. Selain itu, parameter di dalam skor ini memiliki performa yang cukup memuaskan dalam hal diskriminasi pasien dengan risiko mortalitas yang dirawat di ICVCU. Dalam memprediksi mortalitas, parameter di dalam skor ini juga memperlihatkan kalibrasi yang baik. Intermediate ward (IW) sebagai lokasi rawat sebelum masuk ICVCU merupakan prediktor mortalitas yang independen dan pasien dengan komorbid CAP merupakan faktor protektif terhadap mortalitas.

\section{Persetujuan Etik}

Penelitian ini adalah hasil karya sendiri, dan semua sumber yang ikutip maupun dirujuk telah dinyatakan dengan benar dan telah lolos kaji etik

\section{Persetujuan untuk Publikasi}

Semua pihak telah menyetujui publikasi penelitian ini.

\section{Konflik Kepentingan}

Tidak ada konflik kepentingan dalam pelaksanaan penelitian ini.

\section{Daftar Pustaka}

1. Vincent J-L, Moreno R. Clinical review: scoring systems in the critically ill. Crit Care Lond Engl. 2010;14(2):207.

2. Knaus WA, Zimmerman JE, Wagner DP, Draper EA, Lawrence DE. APACHE-acute physiology and chronic health evaluation: a physiologically based classification system. Crit Care Med. 1981 Aug;9(8):591-7.

3. Le Gall JR, Lemeshow S, Saulnier F. A new Simplified Acute Physiology Score (SAPS II) based on a European/North American multicenter study. JAMA. 1993 Dec 22;270(24):2957-63.
4. Rhodes A, Moreno RP, Azoulay E, Capuzzo M, Chiche JD, Eddleston J, et al. Prospectively defined indicators to improve the safety and quality of care for critically ill patients: a report from the Task Force on Safety and Quality of the European Society of Intensive Care Medicine (ESICM). Intensive Care Med. 2012 Apr;38(4):598-605.

5. Metnitz PGH, Moreno RP, Almeida E, Jordan B, Bauer P, Campos RA, et al. SAPS 3--From evaluation of the patient to evaluation of the intensive care unit. Part 1: Objectives, methods and cohort description. Intensive Care Med. 2005 Oct;31(10):1336-44.

6. Moreno RP, Metnitz PGH, Almeida E, Jordan B, Bauer P, Campos RA, et al. SAPS 3--From evaluation of the patient to evaluation of the intensive care unit. Part 2: Development of a prognostic model for hospital mortality at ICU admission. Intensive Care Med. 2005 Oct;31(10):1345-55.

7. Recommendations for the structure, organization, and operation of intensive cardiac care units Oxford Medicine [Internet]. [cited 2017 Dec 10]. Available from: http://oxfordmedicine.com/ view/10.1093/med $/ 9780199687039.001 .0001 /$ med-9780199687039-chapter-10

8. Lott JP, Iwashyna TJ, Christie JD, Asch DA, Kramer AA, Kahn JM. Critical illness outcomes in specialty versus general intensive care units. Am J Respir Crit Care Med. 2009 Apr 15;179(8):676-83.

9. Reina A, Vázquez G, Aguayo E, Bravo I, Colmenero M, Bravo M. Mortality discrimination in acute myocardial infarction: comparison between APACHE III and SAPS II prognosis systems. PAEEC Group. Intensive Care Med. 1997 Mar;23(3):326-30.

10. Granger CB, Goldberg RJ, Dabbous O, Pieper KS, Eagle KA, Cannon CP, et al. Predictors of hospital mortality in the global registry of acute coronary events. Arch Intern Med. 2003 Oct 27;163(19):2345-53.

11. Zimmerman JE, Kramer AA. Outcome prediction in critical care: the Acute Physiology and Chronic Health Evaluation models. Curr Opin Crit Care. 2008 Oct; 14(5):491-7.

12. Capuzzo M, Moreno RP, Le Gall J-R. Outcome prediction in critical care: the Simplified Acute Physiology Score models. Curr Opin Crit Care. 
2008 Oct;14(5):485-90.

13. Knaus WA, Draper EA, Wagner DP, Zimmerman JE. APACHE II: a severity of disease classification system. Crit Care Med. 1985 Oct;13(10):818-29.

14. Zimmerman JE, Kramer AA, McNair DS, Malila FM. Acute Physiology and Chronic Health Evaluation (APACHE) IV: hospital mortality assessment for today's critically ill patients. Crit Care Med. 2006 May;34(5):1297-310.

15. G. H. Metnitz P, Moreno R, Almeida E, Jordan B, Bauer P, Abizanda Campos R, et al. Supplementary Material. 2005 Aug 17;

16. Altman DG, Vergouwe Y, Royston P, Moons KGM. Prognosis and prognostic research: validating a prognostic model. BMJ. 2009 May 28;338:b605.

17. Lemeshow S, Hosmer DW. A review of goodness of fit statistics for use in the development of logistic regression models. Am J Epidemiol. 1982 Jan;115(1):92-106.

18. DeLong ER, DeLong DM, Clarke-Pearson DL. Comparing the areas under two or more correlated receiver operating characteristic curves: a nonparametric approach. Biometrics. 1988 Sep;44(3):837-45.

19. Le Gall JR, Loirat P, Alperovitch A, Glaser P, Granthil C, Mathieu D, et al. A simplified acute physiology score for ICU patients. Crit Care Med. 1984 Nov; 12(11):975-7.

20. Hochman JS, Boland J, Sleeper LA, Porway $\mathrm{M}$, Brinker J, Col J, et al. Current spectrum of cardiogenic shock and effect of early revascularization on mortality. Results of an International Registry. SHOCK Registry Investigators. Circulation. 1995 Feb 1;91(3):873-81.

21. Tarvasmäki T, Lassus J, Varpula M, Sionis A, Sund R, Køber L, et al. Current real-life use of vasopressors and inotropes in cardiogenic shock - adrenaline use is associated with excess organ injury and mortality. Crit Care [Internet]. 2016 [cited 2017 Dec 25];20. Available from: https://www.ncbi.nlm.nih.gov/ pmc/articles/PMC4931696/

22. Corrales-Medina VF, Musher DM, Wells GA, ChirinosJA, Chen L, FineMJ.CardiacComplications in Patients with Community Acquired Pneumonia: Incidence, Timing, Risk Factors, and Association with Short-Term Mortality. Circulation. 2012 Jan
1; CIRCULATIONAHA.111.040766.

23. Houck PM, Bratzler DW, Nsa W, Ma A, Bartlett JG. Timing of antibiotic administration and outcomes for Medicare patients hospitalized with communityacquired pneumonia. Arch Intern Med. 2004 Mar 22;164(6):637-44.

24. Mandell LA, Wunderink RG, Anzueto A, Bartlett JG, Campbell GD, Dean NC, et al. Infectious Diseases Society of America/American Thoracic Society consensus guidelines on the management of community-acquired pneumonia in adults. Clin Infect Dis Off Publ Infect Dis Soc Am. 2007 Mar 1;44 Suppl 2:S27-72.

25. Rhodes A, Evans LE, Alhazzani W, Levy MM, Antonelli M, Ferrer R, et al. Surviving Sepsis Campaign: International Guidelines for Management of Sepsis and Septic Shock 2016. Crit Care Med. 2017 Mar;45(3):486. 